\title{
Application of GIS procedure for river terrace extraction from a LiDAR- based digital elevation model: the Sava River Valley NW of Zagreb, Croatia
}

The Mining-Geology-Petroleum Engineering Bulletin UDC: 551.4

DOI: 10.17794/rgn.2019.1.6

Original scientific paper

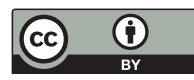

\author{
Neven Trenc'; Bojan Matoš; Josipa Velić'; Dario Perković ${ }^{2}$ \\ ${ }^{1}$ Croatian Agency for Environment and Nature, Radnička cesta 80/7, 10000 Zagreb \\ ${ }^{2}$ Faculty of Mining, Geology and Petroleum Engineering, Croatia, Pierottijeva 6, 10000 Zagreb
}

\begin{abstract}
River terraces and floodplains indicate channel-sediment dynamics and represent important landform features, which can be used to untangle the evolutionary history of climate and tectonic conditions in a certain area. With the availability of high-resolution topographic data, it has recently become feasible to apply GIS procedures for the identification of these subtle landform features. In this study, the TerEx Toolbox, a GIS extension for semiautomatic terrace extraction was applied on the LiDAR based DEM of the Sava River, west of Zagreb in Croatia. The aim of this research was to compare results obtained by TerEx to the existing geological map from the 1970s, which shows sediments of the recent flow (routinely flooded area) and two abandoned Holocene river terraces in the study area. The TerEx output was validated using hillshaded DEM, a historical map of the study area, orthophoto imagery, topographic cross sections and field investigations. TerEx has successfully extracted Holocene terraces and risers shown on the geological map but in some parts of the study area, their position and extent was different. The presented study shows that results obtained by TerEx, in particular if used in combination with other data sources, can effectively focus fieldwork and contribute to new unbiased interpretation of terrain morphology.
\end{abstract}

Keywords:

fluvial morphology, terraces, Holocene, DEM, LiDAR, TerEx (GIS)

\section{Introduction}

River terraces can morphologically be described as a staircase landform consisting of flat areas - or treads separated by steep risers (Hugget, 2007). Aggradational (fill) terraces are typically underlain by a relatively thick layer of alluvial sediments, and the elevated position of treads above large flood level distinguishes terrace surfaces from the river floodplain (Pazzaglia, 2013). An early description and interpretation of river terraces as erosional-sedimentational forms was given by Gilbert (1877) and in accordance with contemporary understanding, their formation can be related (Pazzaglia, 2013, Clement and Fuller 2007; Vandenberghe 2013) to either tectonic activity, change of the erosional base level or climate oscillations and related hydrology and sediment supply changes. This undoubtedly implies that study of Quaternary river terrace systems formation mechanisms and evolution can potentially provide valuable insight into regional tectonics, paleoclimate history and hydrological dynamics.

The recent trend of LiDAR data acquisition, in particular for flood protection, may provide vast amounts of

Corresponding author: Neven Trenc

neven.trenc@gmail.com geomorphological information about Sava River terraces in the near future. The purpose of this study was to test the potential of GIS technologies for terrace extraction on the available LiDAR image of the westernmost section of the river and the obtained results may represent a possible starting point for further application downstream within more comprehensive research.

In our study, we analysed two mapped Holocene aggradational (fill) river terraces along the river Sava, in the vicinity of Zagreb in NW Croatia. The stratigraphic and sedimentological characteristics of the Quaternary terrace sediments, composed predominately of gravel, sand and loess deposits, were comprehensively studied in the past decades (Šikić et al. 1972a; Velić and Saftić, 1991; Saftić et al. 2003 with references). However, following the completion of the basic geological map of the wider area in the 1970s (Sheet Zagreb, (Šikić et al. 1972b), the spatial distribution, morphology and depositional history of Holocene terraces have not been the subject of targeted studies. This lack and time gap in continuous investigations can be partially explained by difficulties related to the recognition of the river terraces due to dense vegetation cover and human activities that mask and reshape their morphological expressions.

The investigated area was predefined by available LiDAR (Light Detection and Ranging) data (see Figure 


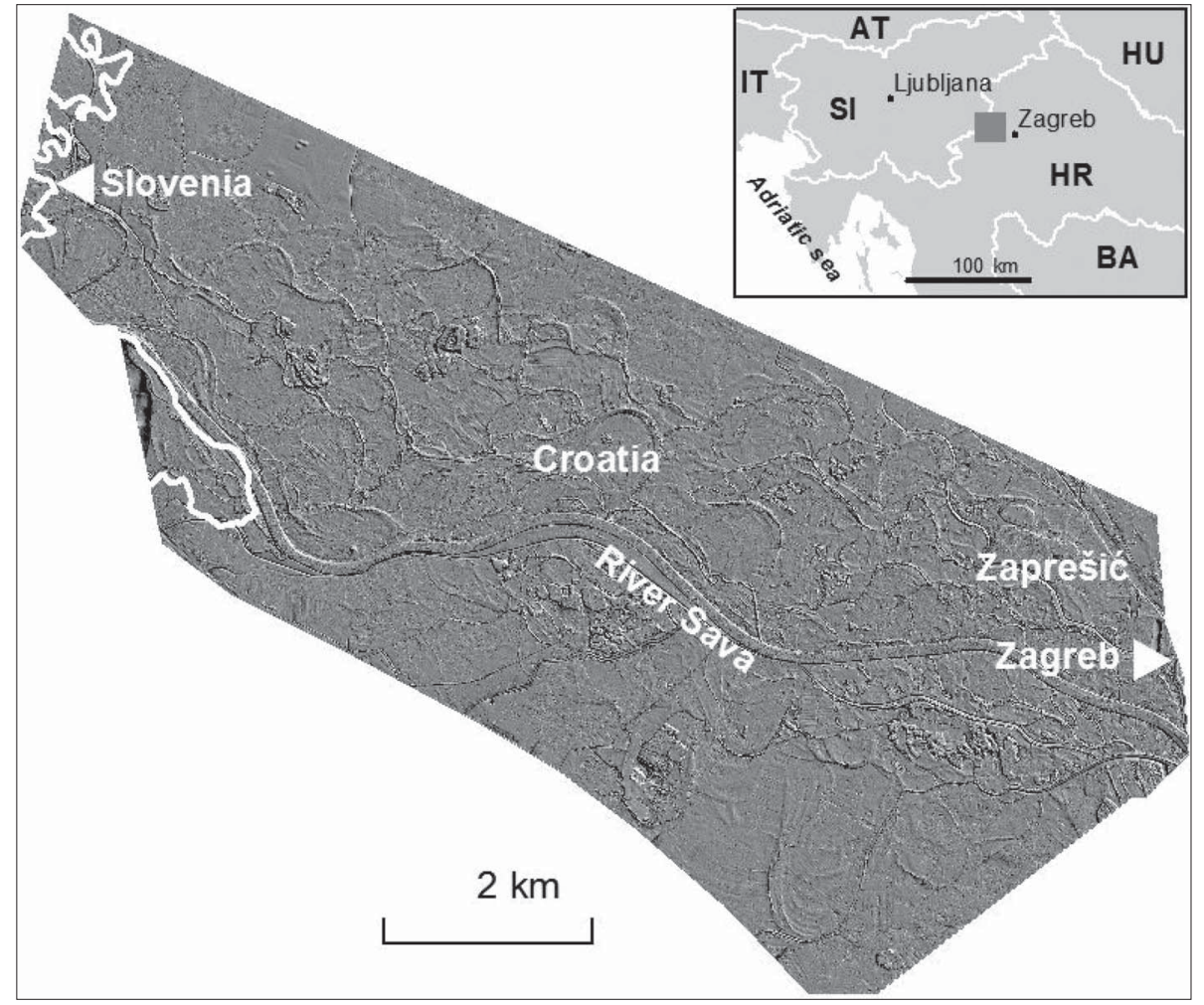

Figure 1: Hillshaded LiDAR DEM data of the study area NW of Zagreb.

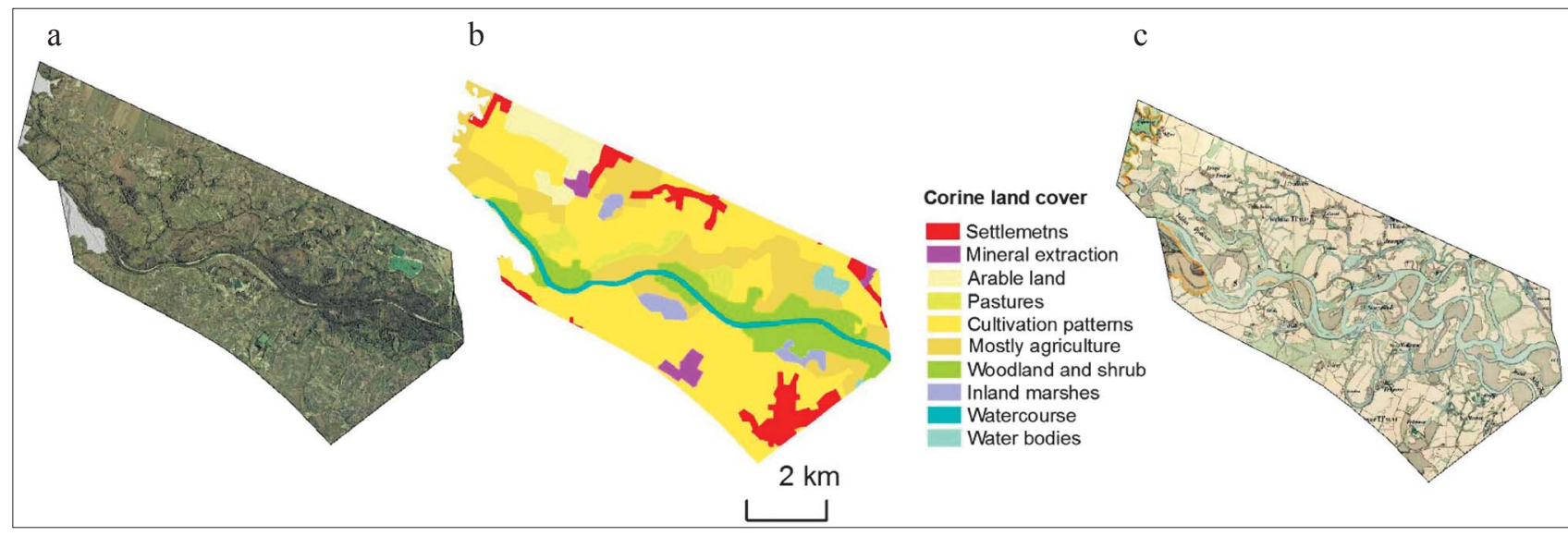

Figure 2: Present and historical land cover river course a) orthophoto image (Geoportal DGU, 2018), b) Corine Land Cover Map; CLC, 2012) c) Historical Map from 1869 (Mapire, 2017))

1), having a length of around $12 \mathrm{~km}$, width of $5 \mathrm{~km}$, and a total area of around $50 \mathrm{~km}^{2}$. Recent land cover in the study area is agricultural with various levels of intensity, while settlements are mostly situated around its edges (see Figure 2). Woodlands and shrubs are present along the recent Sava River course, which passes through its middle. The regulation of the main course of the river in the past 100 years (see Figure 2) and subsequent changes in the flow patterns in the floodplain, as well as agricultural activities, have not only changed land use but have also partially obliterated the initially gentle relief forms. The present morphology is thus the result of interaction between natural processes and human impact.
Correlative to Stout and Belmont (2013), Hopkins (2014), Del Val (2015) and Hopkins and Snyder (2016), various tools and methods for the extraction of river terraces from high resolution digital elevation models (DEM) have been developed in the past decades. As an example, here we concentrate on river terrace extraction using Feature Classification (Wood, 1996), the Rahnis method (Walter et al. 2007), the Demoulin method (Demoulin et. al., 2007) that was adapted for GIS (Geographic Information System) (Cooley, 2015), Edge Detection in MATLAB (Hopkins 2014,), TerEx Toolbox (Stout and Belmont, 2013) and the improved Demoulin method by Del Val (Del Val, 2015). The evaluation of 


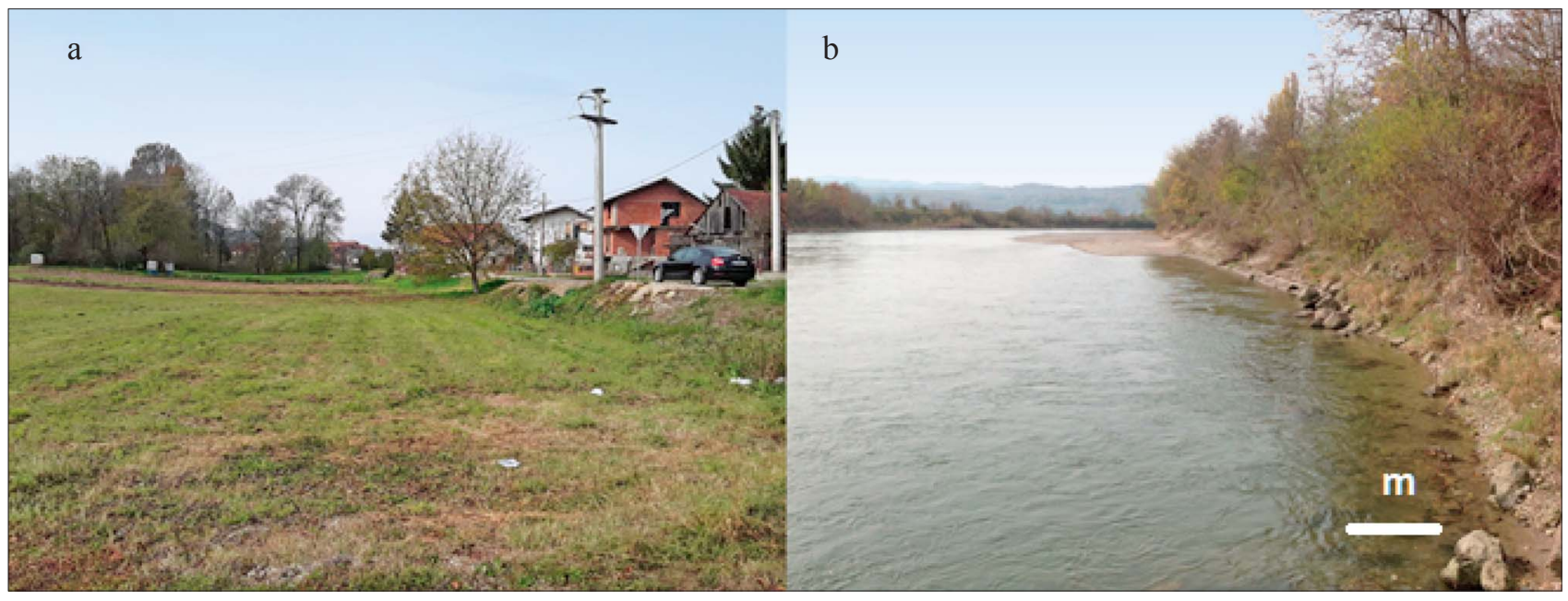

Figure 3: a) Gentle morphology of the area with some doubtful forms near Drenje Brdovečko (Croatia),

b) High paved banks near Sava in the vicinity of the town Jesenice (Slovenia).

results (Hopkins and Snyder, 2016) obtained by three methods (Rahnis Method, Feature Classification Algorithm and the TerEx) has shown that the accuracy of terrace mapping generally decreases in the areas of low relief and that all methods overestimate the terrace area. Advantages of the TerEx Toolbox (Stout and Belmont 2013, Hopkins and Snyder, 2016) include its ability to extract the area of the terraces and the elevation above the river channel segment, applicability in more complex settings and relative accuracy. Another advantage of the results obtained by the TerEx extension is that they can be improved through manual editing and finetuning of input parameters.

The TerEx extension was chosen for this study since it mapped the river terraces in a way that was GIS accessible, allowing correlation of the obtained results with the available geological maps, and has already been tested in river valleys of various sizes and characteristics (Stout and Belmont, 2013; Hopkins and Snyder, 2016). The aim of the conducted research was to extract the extent of Sava Holocene terraces from the acquired high resolution LiDAR dataset using the TerEx procedure and compare the obtained results to an existing geological map. This continuation of the study confirms the already achieved preliminary results but performs (see Trenc et al. 2017) more through quantitative and geomorphological interpretation of the output of semiautomatic procedure.

\subsection{Site Description}

The Sava River has a length of almost 950 km (BabićMladenović et al. 2013) and flows from its source in the Slovenian Alps to the east through Croatia, Bosnia and Herzegovina and Serbia until it reaches its mouth in the Danube. Its catchment is one of the biggest in the Danube River basin and has an area of almost $97,700 \mathrm{~km}^{2}$. The studied section is $12 \mathrm{~km}$ long and positioned at the major knick point near Zagreb (the City of Podsused), which separates the steeper mountainous part from the long meandering lowland section of the river downstream. Due to the vicinity of the state border, the area of the upstream watershed can be approximated as 12,000 $\mathrm{km}^{2}$ and the upstream length of the river as $300 \mathrm{~km}$ based on available data for the Sava catchment portion in Slovenia (Babić-Mladenović et al. 2013; ISRBC, 2014). As calculated from LiDAR data, the studied Sava River section, positioned approximately 700 river kilometres from the mouth (rkm), has a slope of $0.83 \%$ and flows through a relatively wide valley (around $5 \mathrm{~km}$ ). The upstream, confined mountain section has the characteristics of a braided river and a slope of $2 \%$ and more (Babić-Mladenović et al., 2013). The closest downstream section has an average elevation fall of less than $0.2 \%$, flows through a $12 \mathrm{~km}$ wide floodplain, and can be classified as a meandering river. Further downstream from Rugvica, rkm 658 to Belgrade, rkm 0 (the mouth to Danube), the slope is close to $0.05 \%$ (Babić-Mladenović et al., 2013). The distinct hydrography of the studied section visible on 19th century maps (1806-1869) before major regulations (MAPIRE, 2017) shows several strong anastomosing river channels, separated by large vegetated islands. Together with the section position on the transition between the braided and the meandering part of Sava River, it suggests (Schwarz, 2016) that the Sava in this section should be classified as a laterally active gravel dominated anabranching type river (Nanson and Knighton, 1995).

The studied area has a gentle slope towards the southeast that follows the slope of the river. The elevation ranges from $140 \mathrm{~m}$ in the western edge to $120 \mathrm{~m}$ on the eastern side of the study area, with an average elevation of $130 \mathrm{~m}$ (see Figure 3a). The most striking features are the recent regulated sinuous Sava course with paved banks and some embankments, deepened by accelerated erosion and the elevated treads on both sides of the river, which shape a shallow valley (see Figure $3 \mathbf{b}$ ). Other morphological features such as remnants of terrace ris- 
ers, active and abandoned creeks (mostly artificially deepened), some small depressions such as old oxbow lakes have relief up to several meters. Gravel extraction lakes with depths up to $10 \mathrm{~m}$ are located in the area.

The Quaternary tectonic and geological evolution of the Sava Depression, i.e., Sava River Valley has been studied in detail by numerous authors in the past several decades (Šikić et al. 1972a; Velić and Saftić, 1991; Velić and Durn, 1993, Velić et al. 2002; Saftić et al. 2003 with references). The NW-SE striking Sava River Valley in Croatia is c. $560 \mathrm{~km}$ long and bordered by inselbergs (max. elevations of $\leq 800 \mathrm{~m}$ ) of Mt. Medvednica, Moslavačka Gora, and Slavonian Mts. in the NE, whereas to the SW it is bordered by the Žumberačko and Samoborsko gorje, Prosara and Motajica Mts. (see Figure 4).

The tectonic evolution of the Sava River Valley, i.e., Sava Depression is associated with the evolution of the SW Pannonian Basin through the Neogene and Quaternary, which was characterized by complex tectonic phases. Lithospheric extension began in Early to Late Miocene (c. 26-11.5 Ma) due to "back-arc-type" extension of the Pannonian Basin System (PBS). Extension and formation of the Sava Depression and other depocenters in the SW Pannonian Basin were accommodated along NNW-striking listric normal and strike-slip faults that resulted in NE-SW extension (Royden et al. 1983; Horváth et al. 2006). Extension yielded initial deposition of synrift sediment successions (c. 26-6.5 Ma) that involved alluvial and freshwater lake clastics (Ottnangian-Karpatian in age), which eventually due to Badenian marine inundation evolved into breccia-conglomerates and coarse grained sandstones, and locally lithothamnion and bioclastic limestones (Lučić et al. 2001; Velić et al. 2002; Saftić et al. 2003). Besides tectonic inversion that commenced at the end of Middle Miocene (c. 13.0-11.6 Ma; Velić et al. 2002; Saftić et al. 2003; Malvić and Velić, 2011), during the Late Miocene to early Pliocene (c. 11.5-5.3 Ma) lithosphere cooling and deepening of the PBS accommodated further deposition of shallowing upward sequences consisting of delta-related clastics in the shallower and deep-water turbidites in the deepest parts (Royden and; Tomljenović and Csontos, 2001; Saftić et al. 2003).

Prevailing extension, transtension and deepening of existing depocentres was gradually replaced with transpression and compression during the Pliocene and Quaternary periods. This regional change in stress regime was associated with continuing convergence between the Adria microplate and European plate, and NE-ward translation and $\mathrm{CCW}$ rotation of the Adria microplate (e.g., Fodor et al. 1999). As a result, transpressional and compressional stress regimes yielded structural reactivation and tectonic inversion of inherited transcurrent, normal and reverse faults (Prelogović et al. 1998; Fodor et al. 1999; Rukavina et al. 2016 with references). Tectonic uplift of surrounding inselbergs in the vicinity of the Sava River Valley was supplemented with tectonic activity of NW-SE striking reverse faults and reversely reactivated faults (Prelogović et al. 1998; Tomljenović and Csontos, 2001; Fodor et al. 1999), formation of fold belts and formation of positive flower structures (Prelogović et al. 1998; Tomljenović and Csontos, 2001; Matoš, 2014). In this final tectonic stage in the evolution of the Sava Depression, sediment deposition was restricted to lacustrine remnants of Lake Pannon, marshes, and a few alluvial systems. This resulted in variable sediment succession thicknesses ranging between a few tenths of meters to more than $1500 \mathrm{~m}$ of Pliocene, Pleistocene and Holocene clastics (see Figure 4; Velić et al. 2002; Saftić et al. 2003, with references). During the Quaternary period, deposition of the poorly consolidated sediments was highly influenced by sediment influx by the Sava River generally conditioned by an interchange of glacial and interglacial stages.

The present Sava flow was formed at the beginning of the Holocene due to the subsidence along the faults with Dinaric NW-SE orientation and disintegration of the Neogene and Lower Pleistocene structures trending in the NE- SW direction west of Zagreb. Opening of the Krško gorge (at the western edge of the studied area) permitted formation of the present Sava flow and transportation of the limestone rich fluvial material from Alps downstream. The difference in the composition of the Quartz - Quartzite Pliocene pebbles which had a source in surrounding elevated areas when compared to the limestone rich Holocene gravels transported by the river Sava indicates the age of Sava alluvium and constricts the age of the two younger terraces to Holocene (Šikić et al. 1972a; Velić and Saftić, 1991; Velić and Durn, 1993, Velić et. Al. 1999, Saftić et al. 2003, Baketarić and Cvetković, 2015)

As a result, two Holocene aggradational alluvial terraces (see Figure 4) formed in the studied river section during the Quaternary (additional older Pleistocene terrace is situated upstream), with c. 30 to $115 \mathrm{~m}$ total sediment thickness separated by terrace risers $<2 \mathrm{~m}$ (see Šikić et al. 1972b for details). The constructed Sava River terraces (see Figure 4) are mostly composed of medium to course-grained gravels and well-rounded pebbles of limestones, and to a lesser extent of sand and silt (Velić and Saftić, 1991, Velić and Durn, 1993). The youngest Holocene Sava River terrace sediments are in some portion, in its uppermost sections also influenced by the re-deposition of Holocene loess deposits (Šikić et al. 1972a; Velić and Saftić, 1991; Velić and Durn, 1993 Saftić et al. 2003 with references). In the area along the Sava River course, the geological map also indicates an area of recent Sava sediments routinely flooded by higher water levels (a), composed predominantly of sand and to a lesser extent gravel that are separated from the younger terrace by a $1-1.5 \mathrm{~m}$ high risers. The area along the Sava River, as well as the entire area of younger Holocene terrace has been affected by river regulation in the beginning of 20th century and later 


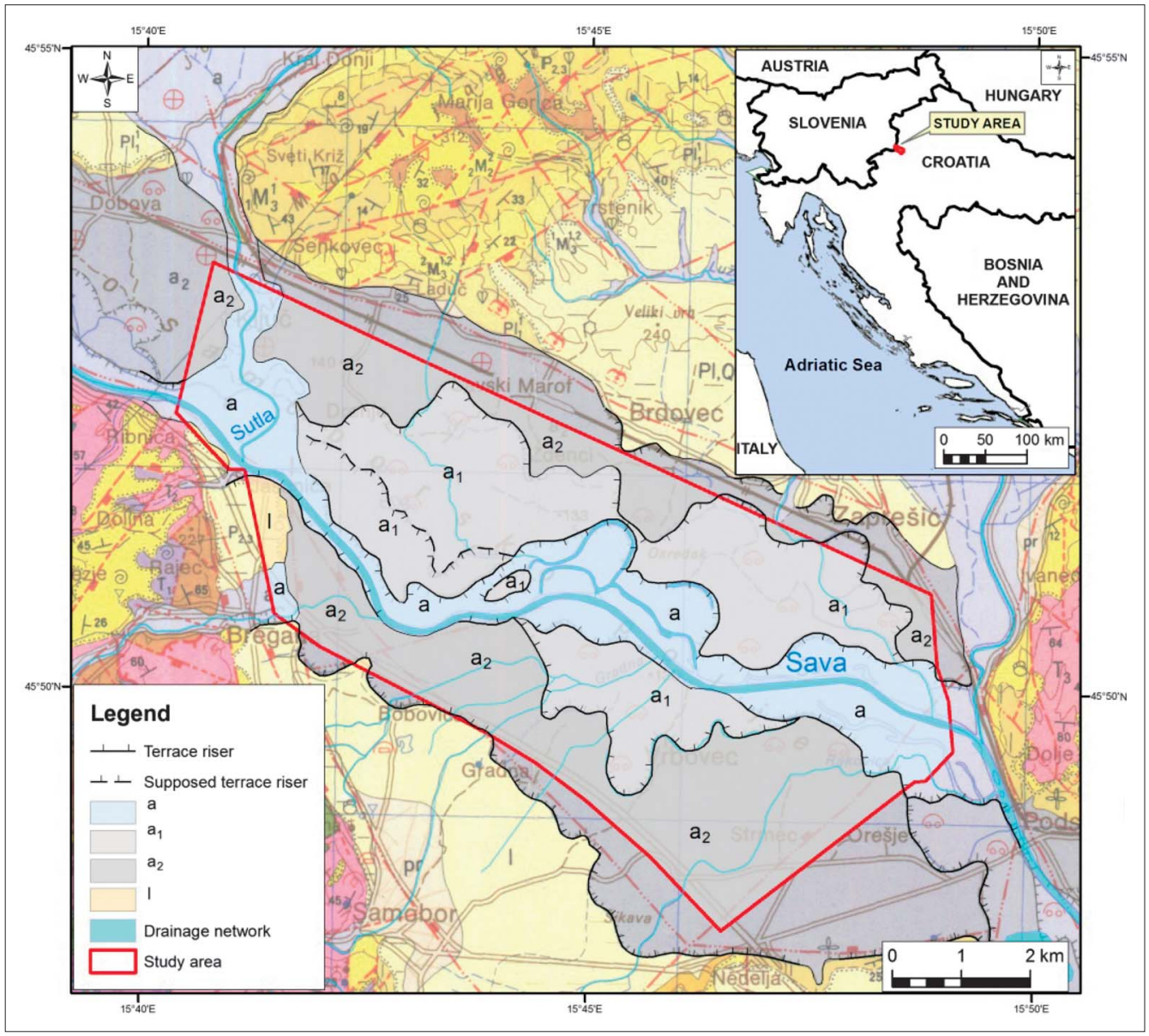

Figure 4: Geological map of the study area (after Šikić et al. 1972b). Study area with the area of available LiDAR data is indicated with a rectangle. Map abbreviations - a-sediments of the recent flow (routinely flooded), a1-younger Holocene Sava River terrace, a2-older Holocene Sava River terrace, 1-Holocene loess deposits.

construction of dams in the upstream area which stopped sediment movement (see Figure 2a). Consequently, these recent morphological features and sediments are not representative for the natural hydro morphological system, which was active in the Holocene except for the last hundred or even less years.

\section{Methods}

A LiDAR image obtained by an airborne scanner was used in the study of Sava River terraces. It was acquired in June 2015 and a path of the plane roughly followed the path of the Sava River in the NW - SE direction from Zagreb (Zaprešić) to the Slovenian border. The acquired dataset (cca 12 × $15 \mathrm{~km}$ ) has horizontal and vertical precision of centimetre to decimetre scale with a vertical RMS error of $0.075 \mathrm{~m}$ and a horizontal error of $0.055 \mathrm{~m}$. Processed bare earth DEM with a constructed grid of 1 $\mathrm{m}$ was used in the morphometric analysis and the dataset already had interpolated presentation of the river. The extent of the image was sufficient for the study since it covered the entire width of Quaternary sediments along the Sava River and included the full extent of the river terraces except for the outer raiser which marks the contact with older Neogene sediments (see Figure 4).

The terrace extraction procedure was performed with the TerEx Toolbox (see Stout and Belmont, 2013 for details) downloaded from the Belmont Hydrology and Fine Sediment Lab (Lab Resources) website at Utah State University (USU, 2017) and paired with ArcGIS version 10.1, in accordance with provided detailed instructions by Stout (2012) and Stout \& Belmont (2013). TerEx is a semi-automatic application in the sense that the operator intervenes into the procedure to obtain the best results. The input data necessary for analysis are usually high resolution DEMs and a line shape file that follows the centre line of the river course. The processing of the data is performed in two stages and several iterations. Entered parameters (in both procedure stages) can be divided in two groups. The first group of parameters is defined by the characteristics of the river and its valley (maximum valley width, stream width at the mouth and reach length). They are measured on the map or DEM and cannot be changed during the iterative process. The parameters in the second group can be changed during the iteration and include: focal window, maximal 
elevation change, terrace area, and smoothing tolerance. The focal window defines the area over which maximum elevation should not exceed a certain value if it is to be classified as a single terrace polygon. In a similar way, the minimum terrace size defines the minimal identified flat area that may be considered as a terrace. The smoothing factor affects the shape of the extracted polygons.

\section{(Stout and Belmont, 2013)}

In the second part of the terrace extraction procedure, the TerEx algorithm extracts the height of each polygon above the closest river centre line segment and stores this information in the attribute table of the polygon GIS layer. In this study, ten iterations were necessary to determine the best set of parameters (maximal elevation change-maximal relief $0.5 \mathrm{~m}$, minimal terrace area 5000 $\mathrm{m}^{2}$, focal window $10 \mathrm{~m}^{2}$, and smoothing factor $100 \mathrm{~m}$ ). Maximal relief value was set to $0.5 \mathrm{~m}$ since that was the presumed minimal height of the risers in the studied area as indicated by field observations. The most sensitive parameters that changed between the iterations were the focal window and minimal terrace area. The accepted values are in agreement with examples in literature (Stout and Belmont, 2013) for aggrading rivers with a watershed above $10000 \mathrm{~km}^{2}$ (the upstream section of the Sava River is $12000 \mathrm{~m}^{2}$, length $\left.200 \mathrm{~km}\right)$, e.g., Minnesota
River, US (watershed $44000 \mathrm{~km}^{2}$, length $600 \mathrm{~km}$ ), (Stout and Belmont, 2013).

\section{Results}

In our study, one of the assumptions used was that elevations of the polygons should belong to three distinct elevation groups corresponding to: recent flow sediments (a) younger Holocene (a1) and older Holocene (a2) which are separated by $0.5 \mathrm{~m}$ to approx. $2.0 \mathrm{~m}$ high risers. For that purpose, the natural breaks (jenks) ArcGIS function was used to delineate the three polygon/elevation groups (the upper and lower extreme values with small associated areas were excluded) in the acquired data. Visualization of the break values can be seen in Figure 5 which shows a histogram with polygon elevations on the $\mathrm{x}$-axis (increment of $0.1 \mathrm{~m}$ - which is close to the vertical resolution of the dataset) and the total area of polygons belonging to the increment slot on the y-axis.

Based on the shapes and position of the polygons which aligned partially to the known terrace boundaries in many parts of the study area, the automatically obtained natural breaks were manually shifted to achieve the best possible alignment where the association of the

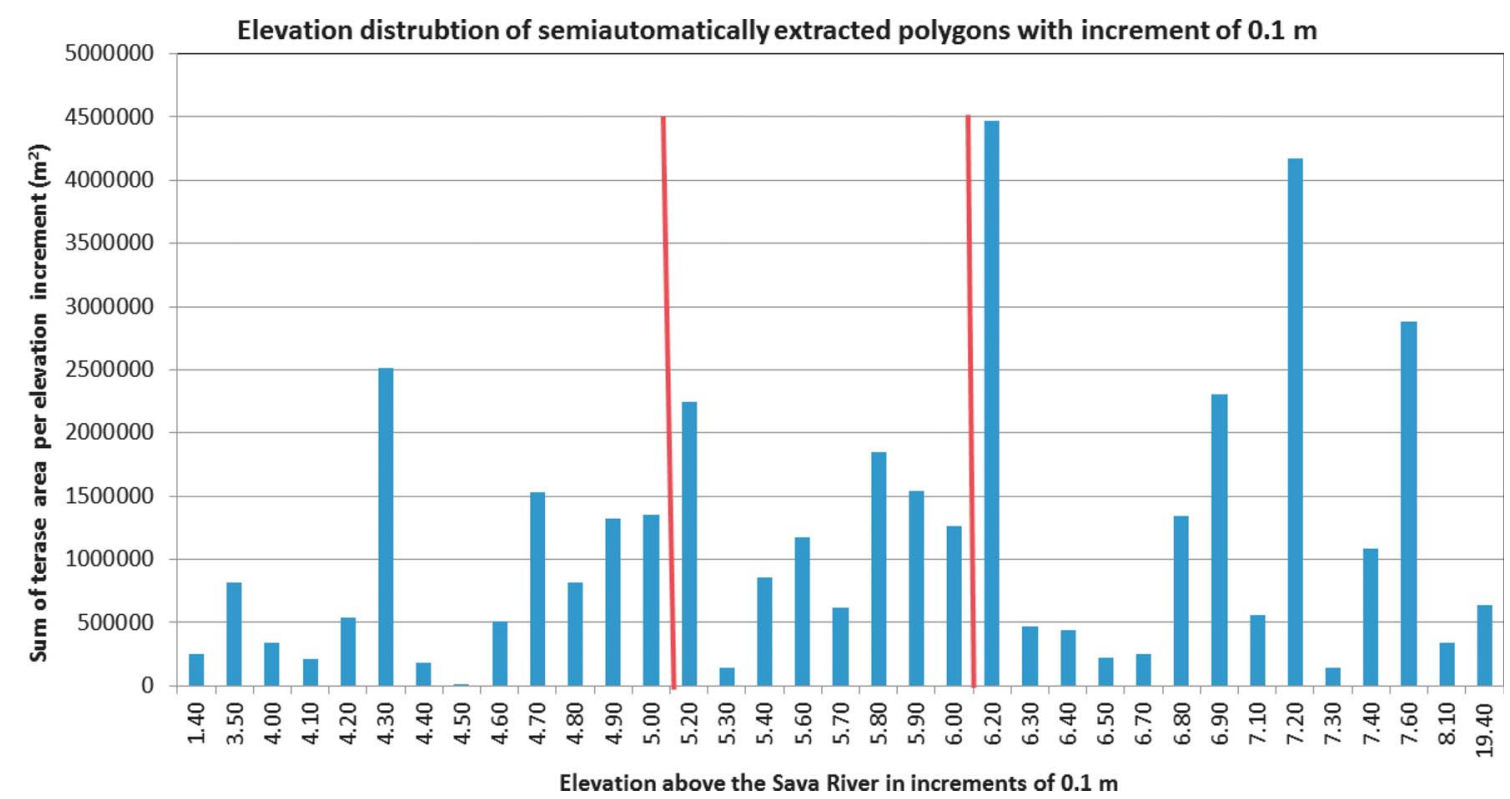

Figure 5: Distribution of the extracted surfaces based on the elevation above the closest river segment with 0.1 increments. Red lines indicate three proposed initial polygon elevation groups which were used in further analysis to identify terraces. Polygon elevation increments with generally small frequency can be identified in its centre with values ranging between 5.3-5.7 m

Table 1: Initial grouping of TerEx polygons based on elevation above the river course (before further geomorphological analysis).

\begin{tabular}{|l|l|l|l|l|l|l|}
\hline $\begin{array}{l}\text { Elevation surface } \\
\text { group }\end{array}$ & $\begin{array}{l}\text { Sum of polygon } \\
\text { area (M2) }\end{array}$ & $\begin{array}{l}\text { Number } \\
\text { of polygons }\end{array}$ & $\begin{array}{l}\text { Average size } \\
\text { (M2) }\end{array}$ & $\begin{array}{l}\text { Elevation } \\
\text { range }\end{array}$ & $\begin{array}{l}\text { Weighted average } \\
\text { elevation (M) }\end{array}$ & $\begin{array}{l}\text { Height } \\
\text { difference (M) }\end{array}$ \\
\hline I & 9978218.29 & 23 & 415759.10 & $3.5-5.19$ & 4.41 & \\
\hline II & 9844845.32 & 17 & 410201.89 & $5.2-6.10$ & 5.63 & 1.22 \\
\hline III & 14630782.68 & 17 & 609615.94 & $6.1-8.14$ & 7.14 & 1.52 \\
\hline
\end{tabular}


polygon to a certain terrace was evident and its elevation was less than $0.3 \mathrm{~m}$ from the threshold defined by ArcGIS. Polygons classified in this way are shown in Figure 5. The obtained results are summarized in Table 1.

The three proposed polygon groups have a weighted average elevation above the closest rivers segment of $4.41 \mathrm{~m}, 5.64 \mathrm{~m}$ and $7.14 \mathrm{~m}$.

The obtained data was entered into the GIS system which included the following layers: LiDAR DEM, LiDAR DEM in hillshade representation, orthophoto map and georeferenced historical map from the 19th century (Mapire, 2017), and GIS layer with extracted polygons. In this step, the ArcGIS Spatial Analyst extension was used to extract profile data. These data sources were used interactively during interpretation.
In this work, two Holocene terraces, a younger (a1) and older (a2) one presented on the geological map of the studied area (see Figure 4) were confirmed through the analysis of LiDAR data (see Figure 6), however the extent of the extracted terraces differs in some portions. Analysis of the spatial distribution and elevations of the extracted terrace polygons indicates that there are actually only two distinct elevation groups (Levels I and III in Table 1). This reflects the fact that sediments of recent flow shown on the map geomorphologically belong to the younger Holocene terrace (see Figure 6, Figure 7, Figure 8). The extent of the extracted a1 Holocene terrace is greater in the northwestern part of the studied area than on the geological map forming narrowing/ wedging out of the al terrace. In the performed analysis,

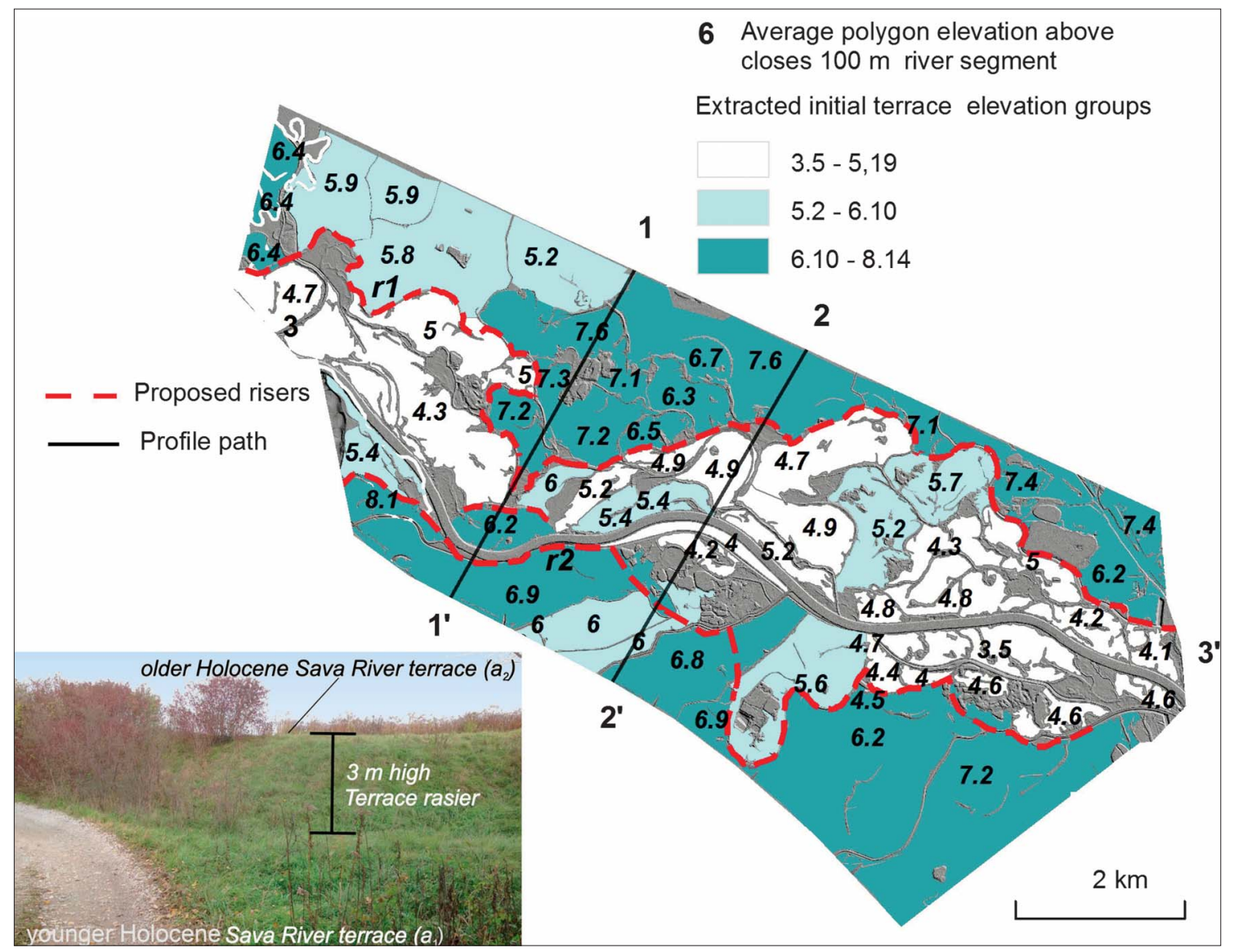

Figure 6: Extracted polygons classified in the potential terrace surfaces with interpreted terrace risers. Topographic profiles shown in Fig. 7 are indicated with numbers 1-1', 2-2' and 3-3'. Inset photograph: Terrace raiser c. $3 \mathrm{~m}$ high between younger (a1) and older Holocene Sava River terrace (a2) according to interpretation based on TerEx. Photo was taken in the vicinity of the Croatian - Slovenian border $\left(\Phi-45.85^{\circ}, \Lambda-15 \cdot 71^{\circ}\right) \mathrm{c}$. $1000 \mathrm{~m}$ NE in relation to the Sava River course (perpendicular to the river centre line).

Table 2: Final grouping of TerEx polygons based on the elevation above the river course and results of geomorphological analysis of all available data

\begin{tabular}{|l|l|l|l|l|l|l|}
\hline $\begin{array}{l}\text { Presumed } \\
\text { terrace }\end{array}$ & $\begin{array}{l}\text { Sum of polygon } \\
\text { area (M2) }\end{array}$ & No polygons & $\begin{array}{l}\text { Average size } \\
\text { (M2) }\end{array}$ & $\begin{array}{l}\text { Elevation } \\
\text { break value }\end{array}$ & $\begin{array}{l}\text { Weighted average } \\
\text { elevation (M) }\end{array}$ & $\begin{array}{l}\text { Height } \\
\text { difference (M) }\end{array}$ \\
\hline a1 & 15172289.83 & 33 & 446243.81 & $<5.7$ & 4.8 & \\
\hline a2 & 23339932.73 & 25 & 933597.30 & $>5.7$ & 6.7 & 1.9 \\
\hline
\end{tabular}


the path and position of the older Holocene terrace risers on the available geological map is supported by the extracted terrace polygons and visual interpretation in GIS (see Figure 6, Figure 8), although their paths do deviate significantly in specific areas.

On the basis of elevation above the river course extracted by the TerEx tool and geomorphological interpretation of the orthophoto imagery, shaded relief DEM and spatial distribution of TerEx extracted segments to known morphological features (risers), the polygons were finally collected into two groups corresponding to the younger Holocene terrace and the older Holocene terrace. The weighted average elevation above the river course was $4.8 \mathrm{~m}$ for the younger Holocene terrace (a1) and $6.7 \mathrm{~m}$ for the older Holocene terrace (a2). The average elevation difference between the terraces which indicates the possible height of risers $\mathrm{r} 1$ and $\mathrm{r} 2$ would be $1.9 \mathrm{~m}$. Outstanding values such as the highest and the lowest value polygon and a single polygon with anomalous value (in respect to surrounding polygons) at the northwestern side of the study area (Elevation 5.2), were excluded from calculation as outliers.

As seen on the histogram in Figure 5, polygon elevation increments with generally small frequency can be identified in its centre with values ranging between 5.3 and $5.7 \mathrm{~m}$. The first (lower) interval with high frequency values can be identified within the elevation range of approximately $4.6-5.2 \mathrm{~m}$, and a second (upper) one in the elevation range between 6.8 and $7.6 \mathrm{~m}$. We assume these two high frequency intervals could roughly represent the range of elevations of the younger and older Holocene terraces (respectively) above the river course. The proposed break value of 5.7 was ultimately selected by geomorphological analysis since, in this way, terrace segment edges fit to the known risers shown on the geological map. Its value, which is outside both of the indicated high frequency ranges, can be explained by the large number of outstanding polygons, which may be related to various natural oscillations of elevations on the terraces and human changes of morphology and potentially to the applied method e.g., errors in interpretation, assumptions and generalisations inherent to the algorithm and imperfections and errors of LiDAR data.

\section{Discussion}

There are two main areas of difference between the previously, geologically established extent of terraces and the results obtained through the interpretation of data by TerEx (see Figure 8, marked by circle). In the area close to the river Sava, in the western part of the study area (along the profile path 1-1', see Figures, 6 and 7) terrace a 2 extends towards the river and connects with the symmetrical terrace a2 developed on the other side of the river forming a narrow elevated area that seems to be cut by the river. In the central-south east part of Figure 6 (profile path 2-2'; see Figures 6 and 7) the large low elevation area between the risers of the oldest a2 Holocene terrace, which was previously mapped as a younger Holocene terrace al and sediments of the recent flow was interpreted as a single terrace (a1) due to similar elevations above the river course and position. A historical map (see Figure 9) from the $19^{\text {th }}$ century shows in this whole area anastomosing natural channels of the Sava River typical for anabranching river types indicating that an active hydro morphological system existed in this area before it was changed by human intervention.

Topographic cross sections 1-1' and 2-2' indicate two Sava River terraces separated by a single riser on each side of the river forming a valley with steep sides and support results obtained by TerEx. Other smaller morphological features visible on the profiles need to be investigated and identified. They could represent risers omitted in the interpretation, smaller creeks with steep banks or other morphological features. In respect to topographic profiles 1-1' and 2-2' that are in general perpendicular to the river course, the longitudinal profile along the Sava River, 3-3' (see Figure 6), has shown a small knick point where the a 2 terrace extends all the way to the river possibly indicating a break through the terrace (a2) as indicated previously.

The areas in the northwestern part of the studied area, with elevation values between the two main groups, were classified as older Holocene terrace (a2) based on their average elevation $(5.8 \mathrm{~m})$ close to the threshold value of $6.1 \mathrm{~m}$ for the older Holocene terrace (a2) and alignment of their edges to the riser (r1). The lower elevation here could be explained by the intensive agriculture activity that may have slightly redistributed the soil on the plots. The remaining two areas obtained by the software with elevation values that differ from the surrounding polygons, could not be classified and these outstanding values may be attributed to human intervention or to some irregularities in terrain, which affected terrace polygon extraction.

The transverse profiles were most useful in the analysis (see Figures 6 and 7 a, b) Due to the relatively small height of the risers if compared to the average slope of the terrain that is almost $1 \mathrm{~m}(0.83 \mathrm{~cm})$ per kilometre, on the longitudinal profile the absolute elevation of the upslope terrace was higher than the downslope regardless of the actual position of the terrace. This tended to hide morphological relationships on the longitudinal profile which could be clearly observed on the transverse profiles. Namely, it has to be kept in mind that heights above the nearest stream segments which are calculated by the software differ from the elevation values above sea level which are obtained directly from DEM.

Field work and analysis of orthophoto imagery performed during this research showed that risers are often covered by vegetation and are rather difficult to detect (see Figure 3). However, as shown in Figure 6, risers that were actually observed in the field were by their po- 


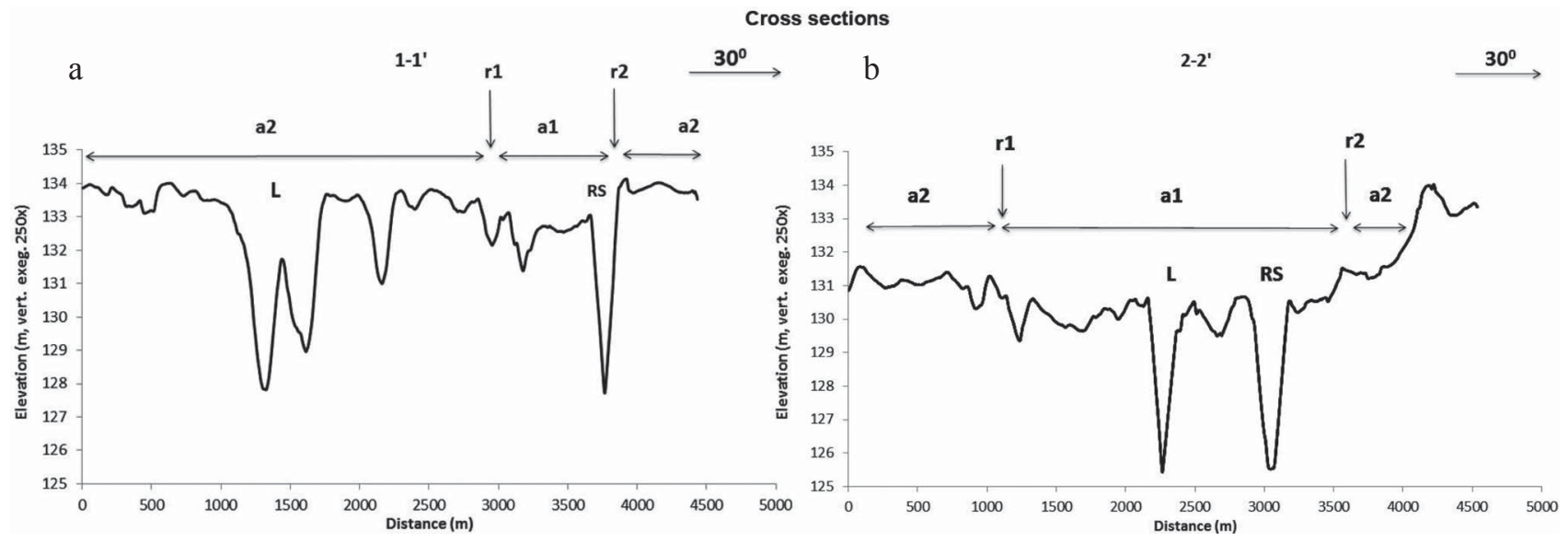

Figure 7: Cross sections: a 1-1', b 2-2., c 3-3', a - recent terrace, a older Holocene terrace,

$\mathrm{L}$ - gravel extraction lake, RS - River Sava

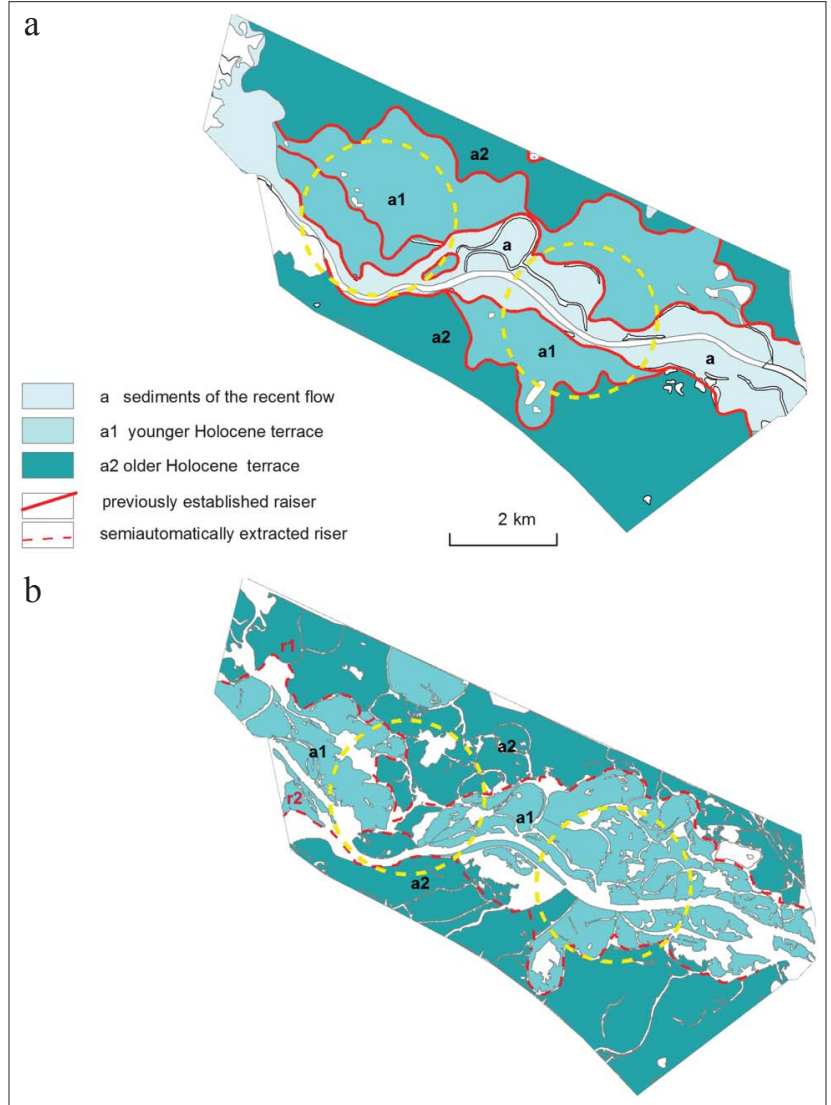

Figure 8: Extent of terraces and risers previously established on the geological map (a) and obtained from TerEx (b). Areas of most significant differences are marked with yellow circles.

sition and height in accordance with the proposed interpretation. They were positioned on the edge of an older Holocene terrace and had a height of c. 2-3 m, which corresponds roughly with the extracted elevation difference between the terraces (see Table 2, Figures 3 and 6). The two risers identified on the hillshade DEM representation were usually marked by steep slopes, embankments and drainage ditches. Intensive agriculture, flood

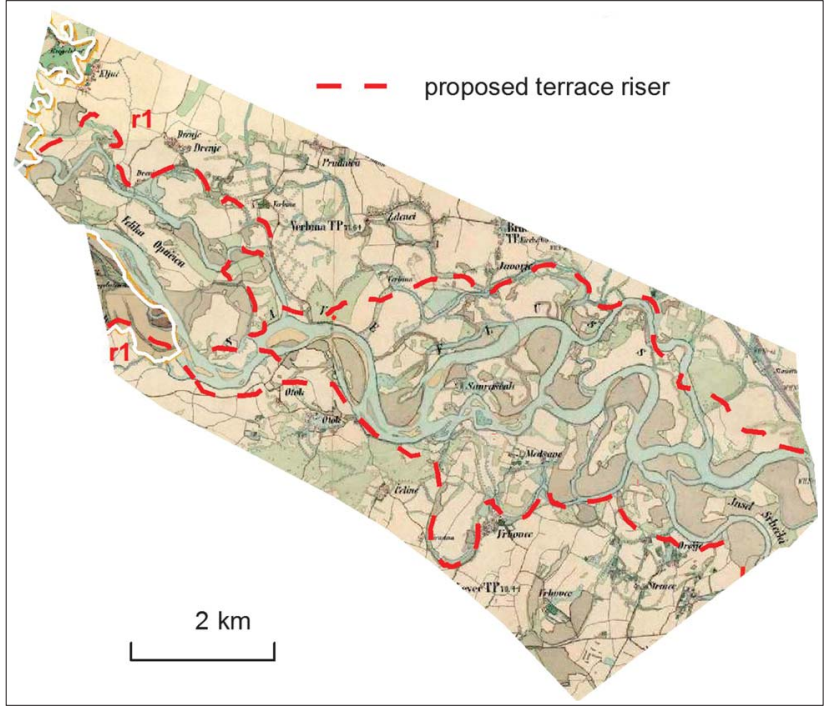

Figure 9: Proposed riser on the 1806-1869 historical topographic map of the study area (Mapire, 2017)

protection, construction of roads and building areas often erase landscape features since they tend to even out steep slopes or stair like forms. Besides the mentioned mistakes of omission, some natural small creeks or manmade features (road banks) can be erroneously identified as terrace risers. In that sense, our results indicate the need for further detailed future work to clarify whether the acquired results represent the true extent of terrace surfaces and positions of risers.

\section{Conclusions}

LiDAR DEM and semiautomatic terrace extraction algorithm TerEx were utilized for the analysis of a 12 $\mathrm{km}$ long section of the Sava River west of Zagreb (Croatia). In addition to the visual interpretation of shaded relief DEM, orthophoto imagery and a historical map, as well as analysis of topographic cross sections were performed. Younger Holocene (a1) and older Holocene (a2) 
terraces present on the geological maps of the studied area (see Figure 6) were confirmed through the analysis of LiDAR data (see Figures. 6 and 8 ) though some differences in their extent and positions of the risers is proposed. The results obtained by TerEx indicate that the area mapped on the geological map as the younger Holocene terrace (a1) and as sediments of the recent flow (routinely flooded) (a) due to similar elevation above the course and extent actually belong to a single younger Holocene terrace. A historical map from the $19^{\text {th }}$ century (see Figure 8) shows an active river course possibly of anabranching character in the entire area between the older Holocene terrace (a2) risers (r1, r2) (see Figure 6) (see Figure 8, indicated by a circle). The division of this area on the geological map into areas of recent flow (a) (routinely flooded) and younger Holocene terrace (a1) reflects changes in morphology associated with human interventions and not the natural hydromorphological characteristic of the area developed through the Holocene period. The extracted older Holocene terrace (a2) extends in the northwestern part of the area close to the river, reduces the extent of the younger terrace and connects with the symmetrical terrace on the other side of the river. The flow patterns on the $19^{\text {th }}$ century historical map which show a concentration of the anabranching flow in this section support this interpretation (see Figure 6) (see Figure 8, indicated by a circle). The results obtained by analysis of the cross sections and initial field data supported these conclusions (see Figure 6). This research shows that the TerEx extension can be a very useful tool for the mapping of river terraces. The results obtained by the software should be carefully interpreted and further cross-checked in the field. Also, all available geological, geographical and land cover data should be included in the analysis. Due to the objective nature of the procedure, which besides a minor input of the operator relies solely on the elevation data, its results can provide new insight into the morphological setting of an already studied area.

In this study, TerEx was an indispensable tool for utilizing the full potential of the high resolution of LiDAR data in the interpretation of river terraces. However, the obtained results can only be used as an indication and guidance for further field work and detailed reconstruction of Holocene geological history of this section of the Sava River.

\section{Acknowledgment}

This study was supported by the Faculty of Mining, Geology and Petroleum Engineering (University of Zagreb) and the Croatian Agency for Environment and Nature (the Republic of Croatia). The authors would like to thank PROGRAM SAVA d.o.o. for providing LiDAR data for this research and to Justin C. Stout and Patrick Belmont for instruction in the use of the TerEx application. We would like to thank Borna Lužar Oberiter, Jus- tin C. Stout, and the editors for reviewing the paper and for comments that greatly improved its quality.

\section{References}

Babić-Mladenović, M., Bekić, D., Grošelj, S., Kupusović T., Mikoš, M. \& Oskoruša D. (2013): Towards Practical Guidance for Sustainable Sediment Management using the Sava River Basin as a Showcase, Estimation of Sediment Balance for the Sava River, International Sava River Basin Commission, p. 87, http://www.savacommission. org/dms/docs/dokumenti/documents_publications/publications/other_publications/balses_final.pdf

Baketarić, T; Cvetković, M., (2015): Subsurface Modelling of the Neogene-Quaternary Sediments in Part of the Sava Depression Based on Digitalization of Legacy Map Data, The Mining-Geological-Petroleum Engineering Bulletin - Rudarsko-geološko-naftni zbornik, (0353-4529) 30 (2015), 2; $67-84$

CLC (2012) CORINE Land Cover Hrvatska (2012) (AZO, 2013).

Clement, A. J. H. \& Fuller, I. C., 2007. Fluvial responses to environmental change in the North Island, New Zealand, during the past c. $30 \mathrm{ka}$ recorded in river terrace sequences: A review and model for river behaviour. New Zealand Journal of Geology and Geophysics, 50(2), 101-116.

Cooley, S.W. (2015): GIS4Geomorphology: http://www.gis4 geomorphology.com (Accessed May 17, 2018)

Demoulin A., Bovy B., Gilles R. \& Cornet, Y. (2007): An automated method to extract fluvial terraces from digital elevation models: The Vesdre valley, a case study in eastern Belgium, Geomorphology, Volume 91, Issues 1-2, 30 October 2007, 51-64.

Fodor, L., Csontos, L., Bada, G., Györfi, I. \& Benkovics, L. (1999): Tertiary tectonic evolution of the Pannonian basin system and neighbouring orogens: a new synthesis of paleostress data. The Mediterranean Basins: Tertiary extension within the Alpine Orogen. Geological Society of London, Special Publications 156, 295-334.

Geoportal DGU (2018), Geoportal Državne geodetske uprave Republike Hrvatske, https://geoportal.dgu.hr/

Gilbert, G. K. (1877), Report on the Geology of the Henry Mountains,., U.S. Govt. Print. Off., Washington, D. C., p. 170

Hopkins, A. J. (2014): Comparison of DEM-based methods for fluvial terrace mapping and sediment volume calculation: Application to the Sheepscot River Watershed, Maine, 113 pp, http://hdl.handle.net/2345/bc-ir:104046,

Hopkins, A. J. \& Snyder, N. P. (2016): Performance evaluation of three DEM-based fluvial terrace mapping methods, Earth Surface and Processing, Volume 41, Issue 8. 41, $1144-1152$

Horváth, F., Bada, G., Szafián, P., Tari, G., Ádám, A. \& Cloetingh, S. (2006): Formation and deformation of the Pannonian basin: constraints from observational data. In: Gee, D.G., Stephenson, R.A. (Eds.), European Lithosphere Dynamics, Memoirs, Geological Society, London, Vol. 32., $191-206$. 
Hugget, R. J. (2007): Fundamentals of geomorphology, Second Edition, Routledge, 447 p.

ISRBC (2014): Sava River Basin Management Plan, International Sava River Basin Commission, Zagreb, $240 \mathrm{p}$ (http://www.savacommission.org/srbmp/en/draft)

Lučić, D., Saftě, B., Krizmanč, K., Prelogovë, E., Britvě, V., Mesić,I.\& Tadej, J. (2001):The Neogene evolution and hydrocarbon potential of the Pannonian Basin in Croatia. Marine \& Petr. Geol., 18, 133-147.

Malvić, T. \& Velić, J. (2011): Neogene Tectonics in Croatian Part of the Pannonian Basin and Reflectance in Hydrocarbon Accumulations. In: SCHATTNER, U. (ed.): New Frontiers in Tectonic Research:At the Midst of Plate Convergence. InTech, Rijeka, 215-238.

MAPIRE (1917): Franziszeische Landesaufnahme (18061869), Österreichisches Staatsarchiv, Arcanum Adatbázis Kft, http://mapire.eu

Nanson G., Knighton, A. D. (1995) Anabranching rivers: their cause, character and classification Earth surface processes and landforms 21 (3), 217-239

Pazzaglia, F. (2013). 9.22 Fluvial Terraces, In: Shroder, J.; Wohl, E., ed. Treatise on Geomorphology; Fluvial Geomorphology, Vol. 9. San Diego, CA: Academic Press., 379-412,

Prelogović, E., Saftić, B., Kuk, V., Velić, J., Dragaš, M. \& Lučić, D. (1998): Tectonic activity in the Croatian part of the Pannonian basin. Tectonophysics, 297, 283-293.

Royden, L.H., Horváth, F. \& Rumpler, J. (1983): Evolution of the Pannonian basin system, 1. tectonics. Tectonics 2, 63-90.

Rukavina, D., Matoš, B. Tomljenović, B. \& Saftić, B. (2016): Neotectonic active faults in the Eastern Part of Sava Depression : Implications to tectonic evolution based on 2D seismic data and 3D subsurface structural modelling. In: Cvetković, M., Novak Zelenika, K., Horvath, J., Hatvani, I. G. (eds.): 8th Croatian-Hungarian and 19th Hungarian geomathematical congress "Geomathematics - present and future of geological modelling”, Trakošćan, Proceedings, 129-137.

Saftić, B., Velić, J., Sztanó, O., Juhász, G. \& Ivković, Ž. (2003): Tertiary Subsurface Facies, Source Rocks and Hydrocrbon Resevoirs in the SW Part of the Pannonian Basin (Northern Croatia and South-Western Hungary). Geologia Croatica, 56/1, 101-122.

Schwarz, U. (2016): Sava White Book. The River Sava: Threats and Restoration Potential Radolfzell/Wien: EuroNatur/Riverwatch. p. 147

Šikić, K., Basch, O. \& Šimunić, A. (1972a): Basic geological map of Yugoslavia, M 1:100 000, sheet Zagreb. Geological Survey Zagreb, published by Federal Geological Institute Beograd.

Šikić, K., Basch, O. \& Šimunić, A. (1972b): Explanatory notes for geological map of Zagreb (L 33-80; 1: 100 000) (in Croatian). Geological Survey Zagreb, published by Federal Geological Institute Beograd.

Stout J. (2012): TerEx Tool tutorial: An Arc Toolbox to semiautonomously select and delineate terrace and floodplain features from LiDAR, Utah State University (obtained from the author), $20 \mathrm{pp}$.

Stout J. C. \& Belmont P. (2013): TerEx Toolbox for semi-automated selection of fluvial terrace and floodplain features from LiDAR., Earth Surface Processes and Landforms, 39, 569-580.

Tomljenović, B. \& Csontos, L. (2001): Neogene-Quaternary structures in the border zone between Alps, Dinarides and Pannonian Basin (Hrvatsko zagorje and Karlovac Basin, Croatia). International Journal of Earth Sciences (Geologische Rundschau), 90, 560-578.

Trenc, N. Matoš, B. Velić, J. \& Perković, D. (2017): Application of semi-automated GIS procedure for river terrace delineation on high resolution LiDAR data in Sava river valley NW of Zagreb, Croatia - First results.20th HU and 9th HR-HU Geomathematical Congress "Geomathematics in multidisciplinary science - The new frontier?”(eds.) Hatvani István Gábor ; Tanos, Péter ; Cvetković, Marko ; Fedor, Ferenc (Pécs: Pécs Regional Committee of the Hungarian Academy of Sciences, 175-182.

USU (2017): The Belmont Hydrology and Fine Sediment Lab, Lab Resources, Utah State University, https:/qcnr.usu. edu/labs/belmont_lab/resources.

Del Val, M. D., Iriarte, E., Arrioalabengoa M., Aranbru A (2015) An automated method to extract fluvial terraces from LIDAR based high resolution Digital Elevation Models: The Oiartzun valley, a case study in the Cantabrian Marg, Quaternary International 364, p. 35 - 43

Vanderberghe, I. (2013): River terrace as a response to climatic forcing: Formation processes sedimentary characteristics and sites for human occupation, Quaternary International, 370, 3-11.

Velić, J. \& Saftić, B. (1991): Subsurface spreading and facies characteristics of Middle Pleistocene depostis between Zaprešić and Samobor. Geološki vjesnik, 44, 69-82

Velić, J., Weisser, M., Saftić, B., Vrbanac, B. \& Ivković, Ž. (2002): Petroleum-geological characteristics and exploration level of the three Neogene depositional megacycles in the Croatian part of the Pannonian basin. Nafta, 53/6-7, 239-249.

Velić, J. \& Durn, G. (1993): Alternating Lacustrine-Marsch Sedimentation and Subaerial Exposure Phases During Quaternary: Prečko, Zagreb, Croatia. Geologia Croatica, 46/1, 71-90.

Velić, J., Saftić, B. \& Malvić, T, (1999) Lithologic Composition and Stratigraphy of Quaternary Sediments in the Area of the "Jakusevec" Waste Depository (Zagreb, Northern Croatia). Geologia Croatica, 52(2), str.119-130.

Walter, R.C., Merritts, D.J. \& Rahnis, M. (2007): Estimating Volume, Nutrient Content, and Rates of Stream Bank Erosion of Legacy Sediment in the Piedmont and Valley and Ridge Physiographic Provinces, Southeastern and Central PA. Report. PA Department of Environmental A Report to the Pennsylvania Department of Environmental Protection, p. 40.

Wood, J.D. (1996): The geomorphological characterization of digital elevation models PhD Thesis, University of Leicester, UK, 466 pp, https://lra.le.ac.uk/handle/2381/34503, 


\section{SAŽETAK \\ Primjena GIS-a za izdvajanje riječnih terasa na digitalnome modelu terena izrađenome pomoću LIDAR-a, dolina rijeke Save, SZ od Zagreba}

Riječne terase i poplavne ravnice pokazatelj su dinamike korita i sedimenta te predstavljaju važne reljefne oblike koje je moguće iskoristiti za istraživanje razvoja klimatskih uvjeta i tektonskih odnosa. Dostupnost topografskih podataka visoke razlučivosti omogućila je primjenu GIS postupaka za njihovo prepoznavanje. U ovome istraživanju TerEx Toolbox, GIS aplikacija za poluautomatsko izdvajanje terasa primijenjena je na DEM izrađen pomoću LiDAR-a za područje rijeke Save u Hrvatskoj zapadno od Zagreba. Cilj je istraživanja bio usporediti osnovnu geološku kartu izrađenu sedamdesetih godina prošloga stoljeća koja pokazuje na ovome području sedimente recentnoga toka (redovito plavljen) i dvije holocenske riječne terase. Analiza rezultata TerExa provedena je korištenjem DEM-a prikazanoga kao osjenčani reljef, povijesnih karata, ortofoto snimaka, topografskih profila i terenskih istraživanja. Rezultati su pokazali da je aplikacija TerEx uspješno izdvojila obje holocenske riječne terase i njihove strmce, ali je pokazala neke razlike u njihovu protezanju i smještaju. Provedeno istraživanje pokazuje da rezultati dobiveni pomoću aplikacije TerEx posebice ako se koriste zajedno s drugim izvorima podataka mogu učinkovito usmjeriti terenski rad i doprinijeti novoj nepristranoj interpretaciju morfologije nekoga područja

\section{Ključne riječi:}

fluvijalna morfologija, riječne terase, holocen, DEM, LiDAR, TerEx (GIS)

\section{Authors contribution}

Neven Trenc (MS, GIS/RS; geomorphology), Principal researcher, provided overview of automatic river terrace extraction techniques, and LiDAR dataset characteristics. Performed TerEx, GIS and quantitative analysis and visual interpretation, performed field work with members of the team and contributed to the geomorphological interpretation of the results, preparation and writing of the manuscript and preparation of the graphics. Bojan Matoš, (Ph.D., Assistant Professor, Structural Geology Geomorphology, GIS) Defined the research concept (plan and general methodological approach of the research), provided data of geological and geomorphological background of the study area, performed field work and contributed to the analysis of LiDAR DEM data, geomorphological interpretation of the results, writing and reviewing of the manuscript, and preparation of the graphics. Josipa Velić, (Ph.D., Professor Emerita, Quaternary Geology and Geomorphology) provided expertise in relation to the Quaternary stratigraphy and geological evolution of the research area, performed field work with members of the team, contributed to the geological and geomorphological interpretation of the data and reviewing of the manuscript and graphics. Dario Perković, (Ph.D., Assistant Professor, geoinformatics GIS/RS), provided input in regards to GIS analysis and reviewed results of the LiDAR DEM interpretation, quantitative analysis and the manuscript and prepared an overview of a geological map. 